[14] Peltier, M. R., Faux, D. S., Hamblin, S. D., Silver, R. M., Esplin, M. S. (2010). Cytokine production by peripheral blood mononuclear cells of women with a history of preterm birth. Journal of Reproductive Immunology, 84 (1), 111-116. doi: 10.1016/j.jri.2009.10.002

[15] Lohsoonthorn, V., Qiu, C., Williams, M. A. (2007). Maternal serum C-reactive protein concentrations in early pregnancy and subsequent risk of preterm delivery. Clinical Biochemistry, 40 (5-6), 330-335. doi: 10.1016/j.clinbiochem.2006.11.017

[16] Nagaraj, R. S., Anand, K. P. (2017). Study of serum high sensitive C-Reactive protein and ferritin in preterm labor. International Journal of Clinical Biochemistry and Research, 4 (3), 213-215.

[17] De Jong, E. P., de Haan, T. R., Kroes, A. C. M., Beersma, M. F. C., Oepkes, D., Walther, F. J. (2006). Parvovirus B19 infection in pregnancy. Journal of Clinical Virology, 36 (1), 1-7. doi: 10.1016/j.jcv.2006.01.004

[18] Crane, J., Mundle, W., Boucoiran, I., Gagnon, R., Bujold, E., Basso, M. et. al. (2014). Parvovirus B19 Infection in Pregnancy. Journal of Obstetrics and Gynaecology Canada, 36 (12), 1107-1116. doi: 10.1016/ s1701-2163(15)30390-x

[19] Bonvicini, F., Bua, G., Gallinella, G. (2017). Parvovirus B19 infection in pregnancy - awareness and opportunities. Current Opinion in Virology, 27, 8-14. doi: 10.1016/j.coviro.2017.10.003

[20] Karabulut, A., Gok, S., Kocyigit, A. (2013). Non-immune hydrops fetalis without anemia due to parvovirus B19. International Journal of Gynecology \& Obstetrics, 124 (1), 82. doi: 10.1016/j.ijgo.2013.07.021

[21] Hvilsom, G., Thorsen, P., Jeune, B., Bakketeig, L. (2002). C-reactive protein: a serological marker for preterm delivery? Act a Obstetricia et Gynecologica Scandinavica, 81 (5), 424-429. doi: 10.1034/j.16000412.2002.810509.x

[22] Shah, J., Baxi, B. (2016). Identification of biomarkers for prediction of preterm delivery. Journal of Medical Society, 30 (1), 3-14. doi: 10.4103/0972-4958.175790

[23] Rebrova, O. Y. (2006). Statisticheskiy analiz medicinskih dannih: primenenie paketa prikladnuh program Statistica. Moscow: Mediasfera, 312.

\title{
CHANGES IN THE CELL SQUAD OF ILIAC LYMPH NODES OF WHITE RATS IN CASE OF LONGTERM INFLUENCE OF NALBUFIN
}

\author{
Olesya Valko \\ Department of Human Anatomy and Histology \\ Uzhhorod National University \\ 22 Peremohy str., Uzhhorod, Transcarpathian region, Ukraine, 88015 \\ anatomolesya@ukr.net \\ Andrew Holovatskyi \\ Department of Human Anatomy and Histology \\ Uzhhorod National University \\ 22 Peremohy str., Uzhhorod, Transcarpathian region, Ukraine, 88015 \\ holand36@ukr.net
}

\footnotetext{
Abstract

The article presents data on the change in the cellular composition of the lymph nodes of the white rats, males of reproductive age, who received intramuscular opioid analgesics - nalbuphine every day for six weeks. The weekly dose of nalbuphine was gradually increased, creating a model of physical opioid dependence according to the patent of Ukraine No. 76564 U. All experimental animals were divided into 8 groups.

Morphometric method was used to determine the relative number of cells of the lymphoid series - small, medium and large lymphocytes, blasts and plasmocytes in the cloak zone and the embryonic center of the secondary lymphoid nodes and brain strands of the lymph nodes. Morphometric studies were performed using a system of visual analysis of histological preparations.
} 
It was established that nalbuphine in the lymph nodes causes reactive and destructive changes: the number of large lymphocytes increases in all structural components of the lymph node with a maximum after 4 weeks, respectively, the relative number of small lymphocytes decreases in the nucleus centers and brain tracts, the relative number of plasmocytes in the brain strains increases sharply. In all structural components of the lymph nodes hemocapillaries and venules are dilated and full-blooded, around vascular edema and partial damage to the walls of the microvessels.

One week after the discontinuation of nalbuphine, the relative number of lymphoid cells in the structural components of the lymph nodes does not return to the indicators of intact animals, no reversible changes are noted.

Keywords: lymph node, germ center, lymphocyte, plasmocyte, experiment, nalbuphine, white rat.

\section{Introduction}

The study of the influence of narcotic analgesics, in particular opioids, on the immune system of the body, is one of the most important problems, since they are widely used in medical practice [1]. Their medical and social significance is primarily associated with a painkilleractivity $[2,3]$. The opioid is a substance of synthetic and semi-synthetic origin, which is in its composition,morphochemically, related to opiate receptors and provides a certain psycho-vegetative action. The representative of this group is nalbuphine - a synthetic opioid of an agonist-antagonist group (agonist of k-receptors and an antagonist of mu-receptors) [4, 5]. Unfortunately, uncontrolled use of opioids leads to an increase in drug addiction not only in Ukraine, but also in the world [6]. Therefore, the issue of the influence of narcotic analgesics, in particular opioids, on organs and body systems acutely faced by scientists.

Alterations in various organs and systems of the body have been investigated under the influence of nalbuphine, in particular:

- the administration of nalbuphine during 7-28 days leads to dystrophic and destructive changes in the hemocapillary and epitheliocytes of the iris-corneal angle of the eyeball [7];

- Nalbuphine causes a diffuse defeat of the mitochondrial apparatus in all areas of the myocardium [8];

- Changes in the skin are observed, which are accompanied by a violation of its microstructure and the bloodstream [9], changes in the structure of all the vessels of the lining of the eyeball [10], tongue tissues [11, 12];

- Blood vessels of the hemomicrocirculatory pancreas [13] and kidneys [14];

- It has been established that six-week administration of nalbuphine causes pathological changes of angioarchitectonics and neurocytes structures of all layers of the cerebellum cortex [15], etc.

However, the influence of opioids, in particular, nalbuphine, on the immune organs has not been sufficiently studied. The effects of nalbuphine on the thymus, the primary lymphoid organ, have already been studied. It was established that six-week administration of the drug leads to a structural rearrangement of the parenchyma of the organ, deep irreversible changes at the submicroscopic level [16] and damage to the thymus's vascular bed [17]. In the scientific literature, there is no data on the influence of opioids, in particular nalbuphine, on secondary lymphoid organs, in particular lymph nodes, on which not only humoral, but also cellular immunity depends. That is why we are interested in this study. We have already investigated that long-term administration of nalbuphine leads to a change in the relative areas of structural components of the iliac lymph nodes [18] and to destructive changes in the lymph nodes parenchyma at the microscopic level [19].

\section{Aim of the research}

To study the changes in the cellular structure of the structural components of the iliac lymph nodes of white rats-males of reproductive age in the dynamics of the six-week administration of opioid nalbuphine and one week after its discontinuation.

\section{Materials and methods}

This experimental study was performed on 52 non-breeding white male rats of reproductive age (1.5-2 month olds) with an initial weight of 140-150 g. Opioidnalbuphine was injected into test 
animals daily for six weeks in the right intramuscular region of the mitochondria. All experimental animals were divided into 8 groups and the weekly dose of the injection preparation was increased in progressive order (Table 1) according to the patent number $76564 \mathrm{U}$ "Method for the simulation of physical opioid dependence in rats" [20]. The studies were also carried out 1 week after the discontinuation of nalbuphine (group 8).

The research was conducted on the basis of the Lviv National Medical University named after DanyloHalytsky, in accordance with the agreement dated November 18, 2013 on cooperation between the department of normal anatomy of the Lviv National Medical University named after DanyloHalytsky and the Department of human anatomy and histology of the Faculty of medicine of Uzhgorod National University during 2014-2017.

Table 1

Dose of nalbuphine according to experimental groups of animals

\begin{tabular}{|c|c|c|c|c|c|c|}
\hline $\begin{array}{l}\text { Group of } \\
\text { animals }\end{array}$ & $\begin{array}{l}\text { Group } 1 \text { in- } \\
\text { tact animals }\end{array}$ & $\begin{array}{l}\text { Group } 2 \text { af- Group } 3 \text { af- } \\
\text { ter } 1 \text { week of ter } 2 \text { weeks of } \\
\text { introduction introduction }\end{array}$ & $\begin{array}{l}\text { Group } 4 \text { af- Group } 5 \text { af- } \\
\text { ter } 3 \text { weeks of ter } 4 \text { weeks of } \\
\text { introduction introduction }\end{array}$ & $\begin{array}{l}\text { Group } 6 \text { af- } \\
\text { ter } 5 \text { weeks of } \\
\text { introduction }\end{array}$ & $\begin{array}{l}\text { Group } 7 \text { af- } \\
\text { ter } 6 \text { weeks of } \\
\text { introduction }\end{array}$ & $\begin{array}{r}\text { Group } 8 \\
\text { abolition }\end{array}$ \\
\hline $\begin{array}{l}\text { Dose, } \\
\mathrm{mg} / \mathrm{kg}\end{array}$ & - & 15 & 25 & 30 & 35 & - \\
\hline
\end{tabular}

Control was provided with 12 rats, which, in place of nalbuphine, were similarly injected with a $0.9 \%$ solution of sodium chloride.

Experiments on animals were conducted in accordance with the provisions of "The European convention for the protection of vertebrate animals used for experimental and other scientific purposes" (Strasbourg, 1986), Council Directives 86/609/EEC (1986), Law of Ukraine No. 3447-I "On protection of animals from cruel treatment "," General ethical principles of experiments on animals ", adopted by the National congress of Ukraine on bioethics (2001).

The animals were kept in vivarium in accordance with generally accepted rules, on a standard diet. For fetching of the studied organs - the iliac lymph nodes - the experimental animals were extracted from the experiment by anesthetizing the with intraperitoneal anesthesia using thiopental natrium $(25 \mathrm{mg} / \mathrm{kg})$. Fixed material in $10 \%$ neutral formalin, dehydrated in increasing concentrations of ethanol $\left(50^{\circ}, 70^{\circ}, 90^{\circ}, 100^{\circ}\right)$ and poured in paraffin blocks. Histological preparations with a thickness of 5-7 microns stained with hematoxylin and eosin were morphometrically studied to determine the relative number of cellular elements (small, medium and large lymphocytes, lymphoblasts, plasmocytes) of structural components of the iliac lymph nodes of white male rats at prolonged exposure of opioidnalbuphine and 1 week after discontinuation of the drug. Images from the histological preparations on the computer monitor were taken from a microscope MICROmedSEOSCAN and using a VisionCCDCamera. Morphometric studies were carried out using programs VideoTest-5.0, KARRA ImageBase and MicrosoftExel on a personal computer. Statistical processing of digital data was performed using the software "Exel" and "STATISTICA" 6.0 using the parametric method. The digital values are represented by selective mean and standard error $(\mathrm{M} \pm \mathrm{m})$. The reliability of the mean values $(\mathrm{p})$ was determined by the Student's t-criterion with a probability level of $\mathrm{p}<0.05$.

The half-thickness sections 1-2 microns were made on ultramicrotome LKB-3 (Sweden). They were stained with methylene blue.

\section{Results}

The dynamics of changes in the relative number of lymphoid cells were studied - small, medium and large lymphocytes, lymphoblasts, plasmocytes in the cloak zone and the embryonic center of the secondary lymphoid nodes and brain stretches of the lymph nodes of the white rats - males of reproductive age in normal, in the dynamics of six weeks under an influence of the nalbuphine and one week after its cancellation (Table 2, 3, Fig. 1). 


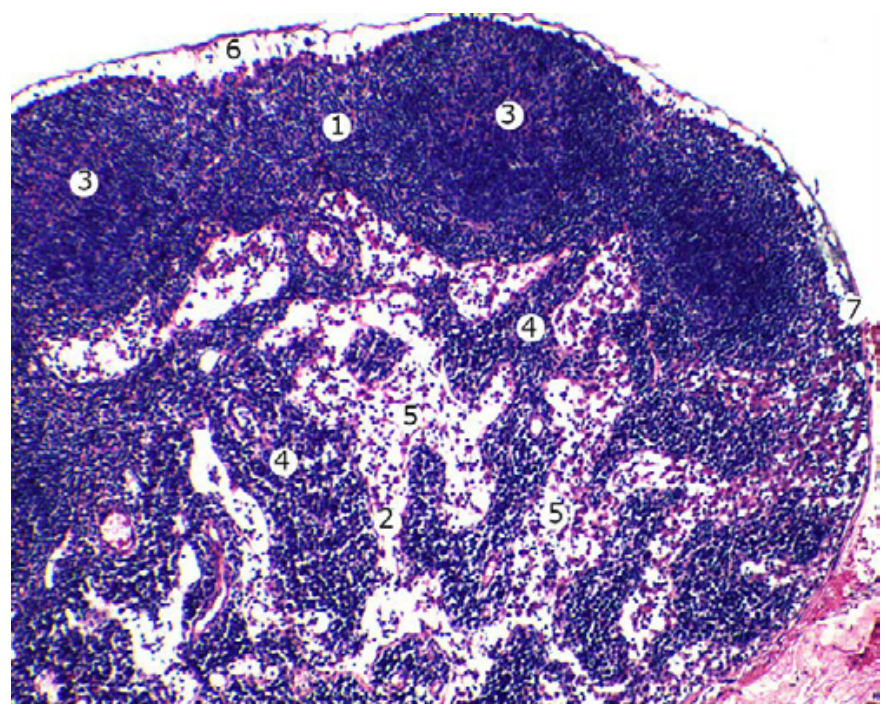

Fig. 1. The structure of the iliac lymph node of the intact white male rat: 1 - cortical substance; 2 - cerebrospinal fluid; 3 - lymphoid knot with a germ center; 4 - brain strain; 5 - the cerebral intermediate lymphatic sinus; 6 - boundary lymphatic sinus; 7 - capsule. Coloring with hematoxylin and eosin. Zoom: op. $\times 10$, oc. $\times 8$

\section{Table 2}

Ratio of the cellular composition of secondary lymphoid nodules of the iliac lymph nodes of white male rats at 6 weeks of opioid nalbuphine exposure and after its cancellation

\begin{tabular}{|c|c|c|c|c|c|c|}
\hline \multirow{3}{*}{$\begin{array}{l}\text { Duration of } \\
\text { nalbuphine }\end{array}$} & \multicolumn{6}{|c|}{ The relative number of cells in the lymphoid series, \% } \\
\hline & \multicolumn{3}{|c|}{ Cloak zone of the lymphoid nodule } & \multicolumn{3}{|c|}{ Embryonic center of the lymphoid nodule } \\
\hline & $\begin{array}{c}\text { Small } \\
\text { lymphocytes }\end{array}$ & $\begin{array}{c}\text { Medium } \\
\text { lymphocytes }\end{array}$ & $\begin{array}{c}\text { Large } \\
\text { lymphocytes }\end{array}$ & $\begin{array}{c}\text { Small } \\
\text { lymphocytes }\end{array}$ & $\begin{array}{c}\text { Medium } \\
\text { lymphocytes }\end{array}$ & $\begin{array}{c}\text { Large } \\
\text { lymphocytes }\end{array}$ \\
\hline Intact animals & $69.47 \pm 2.03$ & $27.84 \pm 1.17$ & $2.69 \pm 0.12$ & $27.93 \pm 1.32$ & $63.54 \pm 2.54$ & $8.53 \pm 0.28$ \\
\hline 1 week & $69.96 \pm 3.04$ & $27.11 \pm 1.14$ & $2.93 \pm 0.14$ & $25.36 \pm 1.27$ & $64.42 \pm 3.02$ & $10.22 \pm 0.37 * *$ \\
\hline 2 weeks & $70.12 \pm 2.95$ & $26.47 \pm 1.25$ & $3.41 \pm 0.17 * *$ & $22.20 \pm 1.23 * *$ & $64.75 \pm 3.06$ & $13.05 \pm 0.32 * * *$ \\
\hline 3 weeks & $70.46 \pm 2.14$ & $25.62 \pm 1.19$ & $3.92 \pm 0.21 * * *$ & $19.92 \pm 1.25^{* * *}$ & $65.17 \pm 3.14$ & $14.91 \pm 0.42 * * *$ \\
\hline 4 weeks & $71.03 \pm 3.21$ & $24.82 \pm 1.12$ & $4.15 \pm 0.16^{* * *}$ & $17.70 \pm 1.19 * * *$ & $66.51 \pm 2.98$ & $15.79 \pm 0.44 * * *$ \\
\hline 5 weeks & $71.34 \pm 3.33$ & $24.64 \pm 1.04^{*}$ & $4.02 \pm 0.12 * * *$ & $18.53 \pm 1.15^{* * *}$ & $65.93 \pm 3.13$ & $15.54 \pm 0.39 * * *$ \\
\hline 6 weeks & $72.03 \pm 3.15$ & $24.13 \pm 1.05^{*}$ & $3.84 \pm 0.22 * * *$ & $19.55 \pm 1.12 * * *$ & $65.47 \pm 2.98$ & $14.98 \pm 0.41^{* * *}$ \\
\hline Cancellation & $72.91 \pm 3.47$ & $23.72 \pm 1.07^{*}$ & $3.37 \pm 0.19 * * *$ & $20.73 \pm 1.14 * * *$ & $64.97 \pm 3.15$ & $14.30 \pm 0.38^{* * *}$ \\
\hline
\end{tabular}

Note:* values that are statistically significantly different from those ones of an intact group of animals: $*_{-p}<0.05 ; * *-p<0.01$; $* * *-p<0.001$

It has been established that in 1-2 weeks of the introduction of nalbuphine changes of the relative number of lymphoid cells in the cloak zone and the embryonic center of the secondary lymphoid nodes and brain strands of the lymph nodes, changes in the cytoarchitectonics of the structural components of the lymph nodes were increasing during the six-week administration of nalbuphine and their cellular composition is not restored, even a week after the drug is cancelled

(Table 2, 3, Fig. 2-6). 


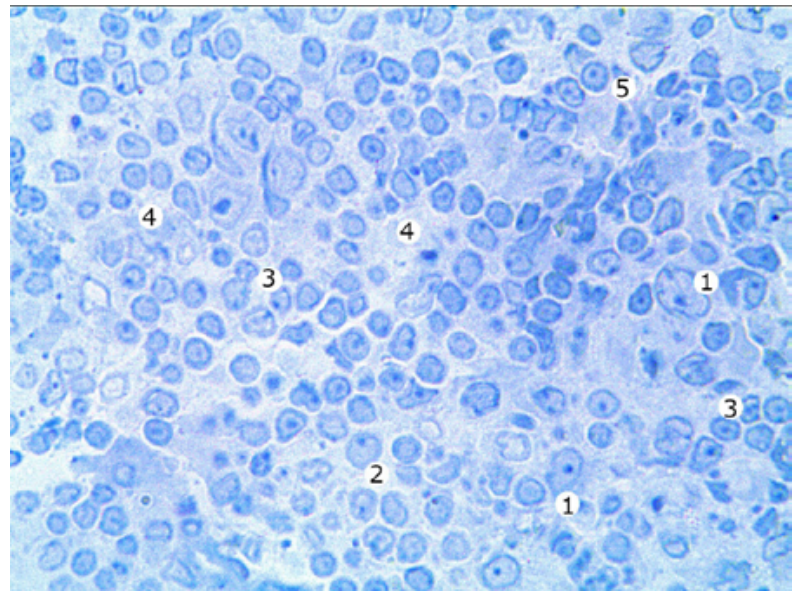

Fig. 2. Fragment of the embryonic center of the lymphoid node of the iliac lymph node of a white male rat after two weeks of nalbuphine administration: 1 - lymphoblast; 2 - middle lymphocyte; 3 -small lymphocytes; 4 - moderately expanded intercellular spaces; 5 -lymphoblast in the stage of mitosis. Thin slice. Coloring with methylene blue. Zoom: $\times 400$
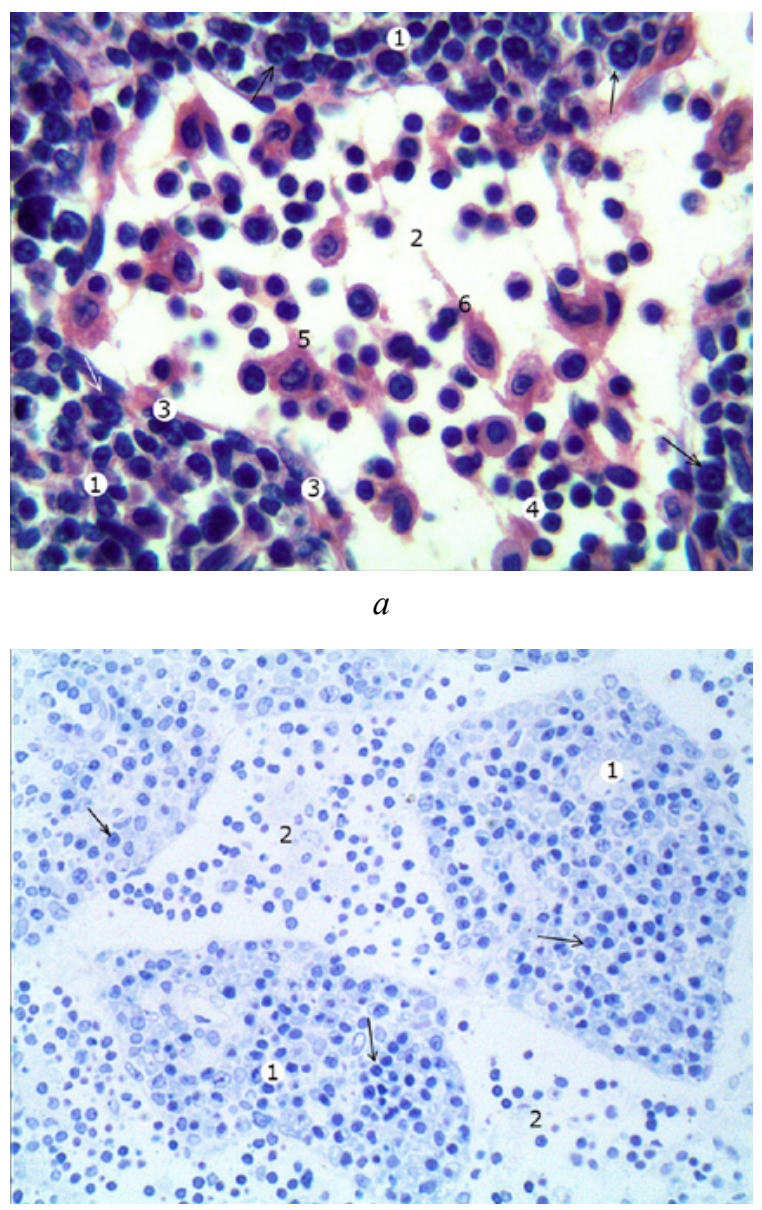

$b$

Fig. 3. Fragment of the brain substance of the iliac lymph node of a white male rat in four weeks of the action of nalbuphine: 1 - cerebral strain; 2 - cerebral intermediate lymphatic sinus; 3 - reticuloendotheliocytus; 4 - small lymphocytes; 5 - macrophage; 6 - reticular cell; plasmocyte (arrow). A - coloring with hematoxylin and eosin. Zoom: op. $\times 40$, oc. $\times 15$. $\mathrm{B}$ is a half-cut slice. Coloring with methylene blue. Zoom: $\times 200$. 
Table 3

The ratio of the cellular composition of cerebral brain masses of the iliac lymph nodes of white male rats at six weeks of exposure to nalbuphine and after its cancellation.

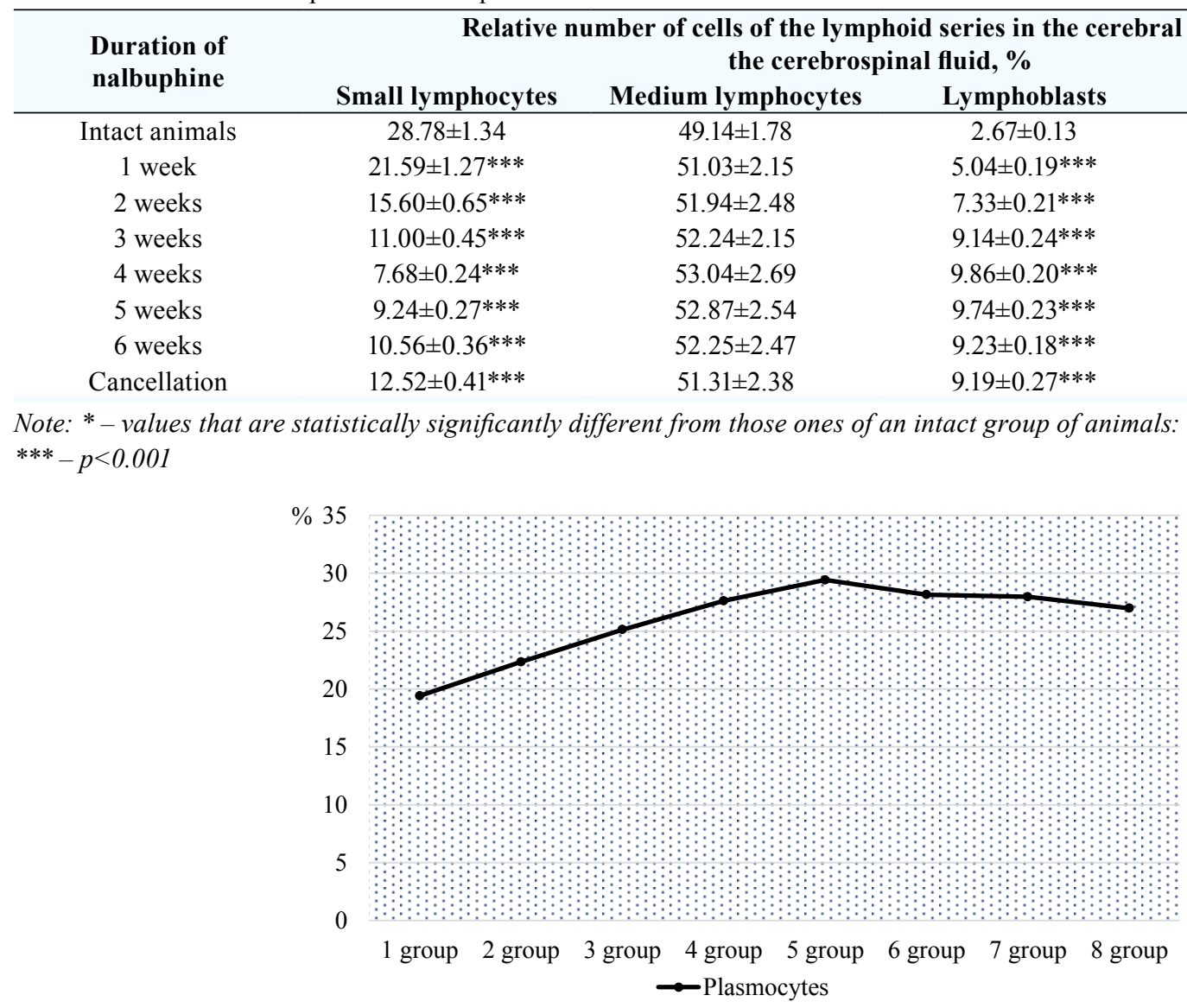

Fig. 4. Changes in the relative number of plasmocytes in the brain strains of the iliac lymph nodes of white male rats in the dynamics of six weeks of opioid nalbuphine exposure:

Group 1 - intact animals; Group 2 - after 1 week; Group 3 - after 2 weeks;

Group 4 - after 3 weeks; Group 5 - after 4 weeks; Group 6 - after 5 weeks;

Group 7 - after 6 weeks; Group 8 - 1 week after cancellation of the drug

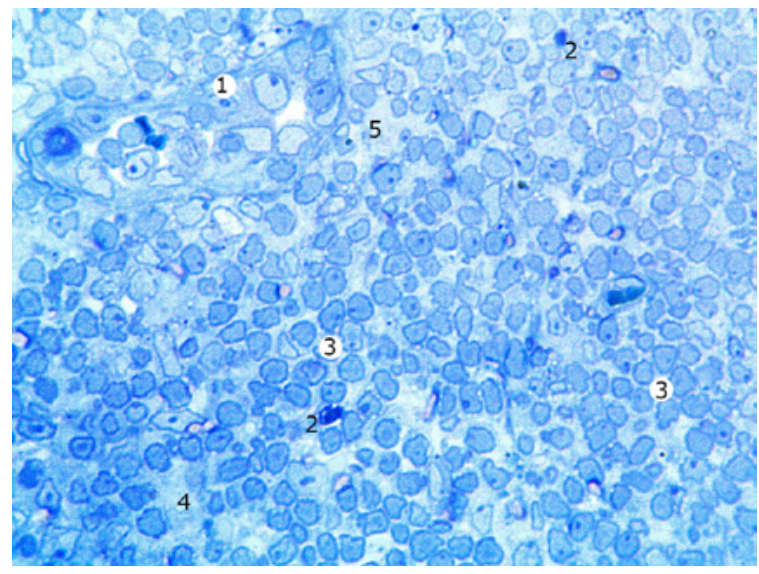

Fig. 5. A fragment of the cloak zone of the iliac lymph nodes male rat after six weeks of nalbuphine administration: 1 - an enlarged vein with a thickened wall; 2 - apoptotic altered lymphocyte; 3 - small lymphocytes; 4 - extended intercellular spaces; 5 - vascular edema. A thin cut. Coloring with methylene blue. Zoom: $\times 400$ 
Following the cancellation of the nalbuphine, pathological changes in the parenchyma, cellular composition of the iliac lymph nodes and vessels of the hemomicrocirculatory channel are

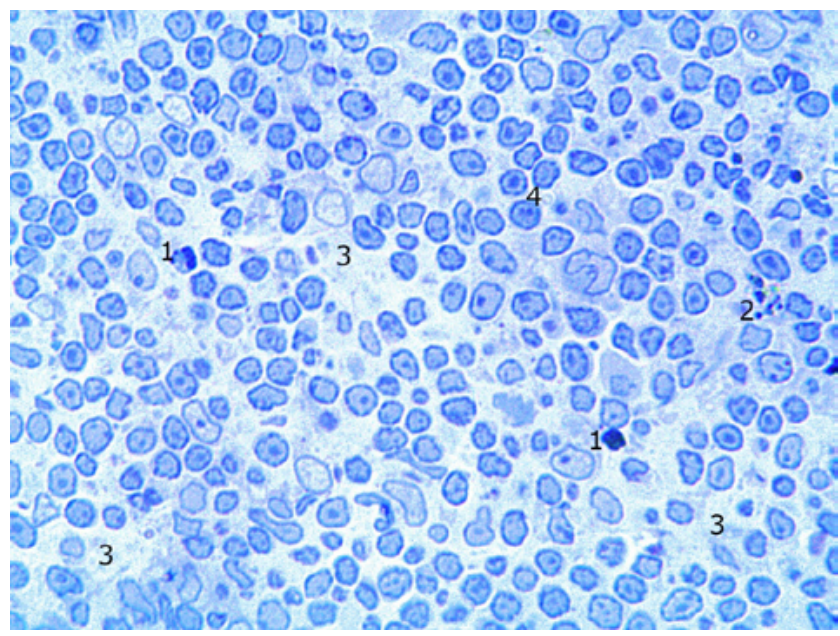

preserved and not restored (Fig. 6).

Fig. 6. Fragment of the embryonic center of the iliac lymph nodes male rat one week after the cancellation of nalbuphine: 1 - apoptotic altered lymphocyte; 2 - macrophage; 3 - extended intercellular spaces; 4 - small lymphocytes. Thin slice. Coloring with methylene blue. Zoom: $\times 400$

\section{Discussion}

The study showed that in normal (intact animals), the germinal centers of the secondary lymphoid nodes of the iliac lymph nodes of white rats-males of reproductive age are predominantly medium lymphocytes and lymphoblasts, and their cloak zone is small lymphocytes (Table 2). There are many plasmocytes in the brain lobes, and middle lymphocytes are also prevalent (Table 3).

At short-term action (within one and two weeks), the reactive changes in the cellular composition of the structural components of the iliac lymph nodes were noted on the body of the experimental animals of nalbuphine. Already after 1 week of experiment in the embryonic centers of secondary lymphoid nodes, the relative number of lymphoblasts $(\mathrm{p}<0.001)$ from $8.53 \%$ (intact animals) to $10.22 \%$ is significantly increased. This indicator increased throughout the experiment with a maximum after 4 weeks of nalbuphine action at $7.26 \%$. Then the amount of lymphoblasts decreases somewhat until the end of the experimental study, but even after 1 week after the cancellation of nalbuphine, the relative number of these cells is significantly higher by $5.77 \%$ compared to intact animals. The relative number of small lymphocytes decreases accordingly, after 4 weeks they are the least $-17.7 \%$, at $27.93 \%$ in animals of the intact group. The relative number of middle lymphocytes is almost unchanged (Table 2).

In the cloak zone of lymphoid nodules of the iliac lymph nodes of intact animals, small lymphocytes prevail $-69.47 \%$. Throughout the experiment, the number of small lymphocytes slightly changes, in contrast to large lymphocytes, which in the cloak zone of intact animals is only $2.69 \%$, but after 4 weeks of action of nalbuphine their number maximally increases to $4.15 \%$. Subsequently, the number of large lymphocytes is gradually decreasing, but even after 1 week after the cancellation of administration of nalbuphine, this indicator does not normalize, remaining significantly $(\mathrm{p}<0,001)$ increased and is $3.37 \%$ (Table 2 ).

Small and medium lymphocytes predominate in brain stretches, the relative number of the latter during the experiment almost does not change (Table 3). Plasmocytes in this structure of the lymph nodes of intact animals are the most $-19.41 \%$. Already after 1 week of action of nalbuphine, the amount of plasmocytes increased to $22.34 \%$. Subsequent daily administration of nalbuphine leads to their maximum increase $-29.42 \%$ after 4 weeks of the experiment. Subsequently, the amount of plasmocytes is somewhat reduced, but even one week after discontinuation of the 
drug, this indicator is significantly $(\mathrm{p}<0.001)$ higher compared to intact animals and is $26.98 \%$ (Table 3, Fig. 4). Also, in the brain strains the relative number of large lymphocytes is significantly increased: after 1 week of the experiment, the relative number of them increases by $2.37 \%$. Subsequently, the number of these cells increases with a maximum of 4 weeks of experiment up to $9.86 \%$. Then the number of large lymphocytes decreases somewhat, but even after 1 week after the abolition of nalbuphine, this figure is greater by $6.52 \%$ compared with intact animals (Table 3). The relative number of small lymphocytes in brain strains under the influence of nalbuphine decreases: after one week of action of the drug - by $7.19 \%$, and after 4 weeks, these cells are the least as much as $21.1 \%$. Subsequently, the number of small lymphocytes increases slightly, but after 6 weeks of experiment they are only $10.56 \%$, and a week after the discontinuation of the drug $-12.52 \pm 0.41$ at $28.78 \%$ in animals of intact group (Table 3).

Comparing the results of the study with the primary lymphoid organ - thymus - where the long-term administration (six weeks) nalbuphine reduces to a slight increase in the density of lymphocytes [21], an increase in the number of lymphoblasts in the embryonic centers and plasmocytes in the brain strands of the lymph nodes suggests the compensatory and adaptive response of this organ to the action of nalbuphine.

\section{Conclusions}

Long-term six-week administration of nalbuphine causes reactive changes in the cellular composition of structural components of the iliac lymph nodes:

1) in the cloak zone of the secondary lymphoid nodes, the relative number of large lymphocytes is increased to $3.84 \%(\mathrm{p}<0.001)$; the relative number of secondary lymphocytes is reduced by $3.71 \%$; the relative number of small lymphocytes does not change substantially;

2 ) in the embryonic center, the relative number of lymphoblasts increases by $6.45 \%$, and the relative number of small lymphocytes decreases by $8.38 \%$; the relative number of middle lymphocytes varies slightly;

3 ) in the brains of the cerebral substance significantly increases the relative amount of plasmocytes - by $8.55 \%$; the relative number of large lymphocytes increases 3.4 times - from $2.67 \%$ to $9.23 \%$, and small lymphocytes - decreases 2.7 times and makes $10.56 \%$ in compare to $28.78 \%$ in intact animals.

One week after the discontinuation of nalbuphine, the relative number of cells of the lymphoid series of structural components of the iliac lymph nodes did not change in comparison with the previous group of experimental animals and did not normalize.

\section{References}

[1] Davydovych, O. V., Kopcha, V. S., Masliy, K. O. (2011). Farmakoterapiya bol'ovoho syndromu. Ratsional'na farmakoterapiya, 4 (21), 66-68.

[2] Hilgemeier, A. T., Serna, D. M., Patel, T. P., Rambaran, K. A., Amin, Z. M., An, J. et. al. (2018). Pain Perception and the Opioid Receptor Delta 1. Cureus, 10 (2). doi: 10.7759/cureus.2149

[3] Rosenblum, A., Marsch, L. A., Joseph, H., Portenoy, R. K. (2008). Opioids and the treatment of chronic pain: Controversies, current status, and future directions. Experimental and Clinical Psychopharmacology, 16 (5), 405-416. doi: 10.1037/a0013628

[4] Ghelardini, C., Mannelli, L. Di C., Bianchi, E. (2015). The pharmacological basis of opioids. Clinical Cases in Mineral and Bone Metabolism, 12 (3), 219-221. doi: 10.11138/ccmbm/2015.12.3.219

[5] Trigub, M. M., Bogdanova, N. G., Kolpakov, A. A., Bashkatova, V. G., Sudakov, S. K. (2014). Effect of Peripheral Opioid Receptor Agonists on Depressive Activity of Ethanol. Bulletin of Experimental Biology and Medicine, 156 (6), 778-780. doi: 10.1007/s10517-014-2448-6

[6] Ehorov, A. Yu., Sofronov, A. H. (2009). Epydemyolohyya i klynycheskye osobennosti narkomanii i toksykomanii podrostkov i molodezhi. Voprosi psykholohii zdorov'ya detey i podrostkov, 9 (1), 22-34.

[7] Yakymiv, N. Ya. (2014). Ul'trastrukturna kharakterystyka struktur rayduzhno-rohivkovoho kuta ochnoho yabluka shchuriv na 7-U, 14-U, 21-U, 28-U dobu opioyidnoho vplyvu. Ukrayins'kyi morfolohichnyi al'manakh, 12 (2), 28-31. 
[8] Dunayev, O. V. (2008). Stan mitokhondrial'noho aparatu peredserdnykh kardio miotsytiv shchuriv v umovakh khronichnoyi narkotychnoyi intoksykatsiyi. Morfolohiya, 2 (1), 57-61.

[9] Diskovs'kyi, I. S. (2014). Osoblyvosti mikrostruktury shkiry za umov vplyvu opioyidu. Ekspernymental'na i klinichna medytsyna, 3, 61-64.

[10] Pidvalna, U. (2015).Compensatory-adaptive peculiarities of vascular tunic of the rat eyeball under the effect of opioid. Folia Medicacassoviensia, 70 (1), 26-27.

[11] Onys'ko, I. O., Onys'ko, R. M., Korol', A. P., Mayevs'kyi, O. Ye. (2013). Zminy na elektronno mikroskopichnomu rivni $\mathrm{v}$ tkanynakh yazyka pid vplyvom malykh doz opioyidu v kintsi 2 i 4 tyzhniv (eksperymental'ne doslidzhennya). VisnykVinnyts'koho Natsional'noho Medychnoho Universytetu, 17 (2), 332-337.

[12] Onys'ko, I. O., Onys'ko, R. M., Mayevs'kyi, O. Ye. (2013). Mikrostrukturni zminy v yazytsi, vyklykani vplyvom malykh doz opioyidu protyahom 70-okh i 84-ty dib (eksperymental'ne doslidzhennya). Ukrayins'kyi morfolohichnyi al'manakh, 11 (2), 72-76.

[13] Popyk, P. M. (2013). Morfomerychna kharakterystyka zmin lanokhemomikrotsyrkulyatornoho rusla pidshlunkovoyi zalozy pid vplyvom nalbufinu. Aktual'ni problemy suchasnoyi medytsyny: Visnyk Ukrayins'koyi medychnoyi stomatolohichnoyi akademiyi, 4 (44), 158-161.

[14] Vil'khova, I. V. (2015). Morfolohichni zminy kanal'tsiv nefrona pry khronichnomu opioyidnomu vplyvi. Svit medytsyny ta biolohiyi, 2 (49), 84-87.

[15] Bekesevych, A. (2015). Vplyv narkotychnykh serednykiv na strukturnu orhanizatsiyu nervovoyi tkanyny. Naukovyi visnyk Uzhhorods'koho universytetu. Seriya «Medytsyna», 1 (51), 218-221.

[16] Harapko, T. V. (2016). Strukturni zminy mozkovoyi rechovyny chastochok tymusa bilykh shchuriv pry shestytyzhneviy diyi opioyidu nalbufinu. Problemy klinichnoyi pediatriyi, (1-2 (31-32)), 19-25.

[17] Harapko, T., Holovatsky, A. (2016). The features of arterial thymusatnalbuphineaction. EUREKA: Health Sciences, 2, 30-37. doi: 10.21303/2504-5679.2016.00091

[18] Val'ko, O. O., Holovatsky, A. S. (2017). Dynamika mikroskopichnykh zmin strukturnykh komponentiv klubovykh limfatychnykh vuzliv pry dovhotryvalomu vplyvi opioyida nalbufinu. Visnyk morfolohiyi, 23 (2), 181-186.

[19] Val'ko, O. O. (2017). Zminy parenkhimy limfatychnykh vuzliv bilykh shchuriv pry tryvalomu opioyidnomu vplyvi ta cherez odyn tyzhden' pislya yoho vidminy. Naukovyi visnyk Uzhhorods'koho universytetu. Seriya «Medytsyna», 1 (55), 5-14.

[20] Onys'ko, R. M., Pal'tov, Ye. V., Fik, V. B., Vil'khova, I. V., Kryvko, Yu. Ya., Yakymiv, N. Ya., Fit'kalo, O. S. (2013). Pat. No. 76564 UA. Sposib modelyuvannya fizychnoyi opioyidnoyi zalezhnosti u shchuriv. MPK F 61 K 31/00. No. u201207124; declared: 12.06.2012; published: 10.01.2013. Bul. No. 1.

[21] Harapko, T. V., Holovatsky, A. S. (2016). Mikroskopichni zminy tymusa shchuriv za dovhotryvalym vplyvom opioyidu. Klinichna anatomiya ta operatyvna khirurhiya, 15 (2 (56)), 55-59. 